\title{
LOKASI OPTIMAL PENGEMBANGAN TPI UNTUK MENDUKUNG PERKEMBANGAN KAWASAN PESISIR KECAMATAN KRAGAN KABUPATEN REMBANG
}

\author{
K.D. Astuti ${ }^{a}$, R.Viyetri ${ }^{b}$ \\ ${ }^{a}$ Universitas Diponegoro, Indonesia, email: khristiana.dwiastuti@undip.ac.id \\ ${ }^{b}$ Universitas Diponegoro, Indonesia, email: ricyeviyetri@ymail.com
}

\begin{abstract}
Article Info;
Abstract: Geographically, District Kragan is located in northern coast of Java in Rembang

Received:

20 September 2014

in revised form:

23 September 2014

Accepted:

25 September 2014

Available Online:

1 October 2014

Keywords: Regency. Based on that, one of the potential sector in the district is marine fisheries. That sector is an alternative livelihood and increase the economy of Rembang Regency. To support the marine fisheries sector, it needed adequate infrastructure, such as fish comercial trader (a.k.a.TPI). There are 3 TPI in District Kragan: TPI Pandangan, TPI Karanglincak, and TPI Karanganyar, but not operating optimally. So, there's less result of productivity, processing and marketing of fish in District Kragan. That problem effect on people's income and revenue of District Kragan. The method that used is quantitative methods, and approach to determine the minimum time and cost, marketing area, and maximum profit. In addition to analyzing the availability of infrastructure and facilities that support the development of coastal areas Kragan is using scoring analysis. Base on that analysis, the optimal location of the development of TPI in the District Kragan is on TPI Padangan because it has a large area, and thus allowing to support the development of TPI and accommodate the availability of infrastructure and facilities.
\end{abstract}

TPI, Coastal Area,

Optimum Location

Info Artikel;

Diterima:

20 September 2014

Hasil Revisi :

23 September 2014

Disetujui:

25 September 2014

Publikasi On-Line:

1 Oktober 2014

Kata kunci:

TPI, Kawasan Pesisir, Lokasi Optimal

\begin{abstract}
Abstrak: Secara geografis Kecamatan Kragan terletak di pesisir pantai utara Jawa di Kabupaten Rembang. Berdasarkan hal tersebut salah satu potensi di Kecamatan Kragan adalah dibidang perikanan laut yang menjadi alternatif mata pencaharian dan salah satu faktor sektor unggulan yang meningkatkan perekonomian. Untuk menunjang sektor tersebut diperlukan sarana dan prasarana yang memadai. Salah satu sarana penunjang pengembangan perikanan laut di Kecamatan Kragan adalah tersedianya Tempat Pelelangan Ikan (TPI). Adanya TPI di Kecamatan Kragan yaitu Desa Pandangan, Desa Karanglincak, dan Desa Karanganyar belum beroperasi secara maksimal. Hal ini yang mendasari pokok permasalahan sehingga dampak yang ditimbulkan adalah kurang maksimalnya hasil produktivitas, pengolahan dan pemasaran ikan di Kecamatan Kragan serta berakibat juga terhadap pendapatan masyarakat dan Pendapatan Asli Daerah (PAD) Kecamatan Kragan. Metode yang digunakan adalah metode kuantitatif, dan alat analisis yang digunakan adalah analisis teori lokasi dengan pendekatan-pendekatan untuk menentukan waktu dan biaya minimum, pendekatan daerah pemasaran dan pendekatan keuntungan maksimum. Selain itu untuk menganalisis ketersediaan prasarana dan sarana yang mendukung perkembangan wilayah pesisir Kragan menggunakan analisis skoring. Melalui analisis tersebut, lokasi optimal pengembangan TPI di Kecamatan Kragan adalah di TPI Padangan karena mempunyai ketersediaan fisik lahan yang luas, sehingga memungkinkan untuk pengembangan kedepannya, dalam mewadahi aktivitas perikanan yang semakin berkembang didukung ketersediaan prasarana dan sarana yang lebih memadai.
\end{abstract}

\section{PENDAHULUAN}

Wilayah Indonesia yang sebagian besar merupakan wilayah lautan memberikan karakteristik tersendiri bagi potensi sumber daya alam yang dimilikinya. Sumber daya alam yang berupa sumberdaya perikanan merupakan salah satu sektor potensial pada kawasan pesisir yang terdapat di seluruh wilayah Indonesia. 
Berkaitan dengan perkembangan wilayah pesisir, salah satu wilayah yang mempunyai potensi dibidang sumberdaya perikanan adalah Kabupaten Rembang yang terletak dipesisir pantai laut utara Jawa. Kabupaten Rembang memiliki potensi yang besar dibidang perikanan baik perikanan tangkap maupun perikanan budidaya. Kabupaten Rembang memiliki panjang pantai $\pm 63 \mathrm{~km}$ yang meliputi enam kecamatan termasuk Kecamatan Kragan. Kecamatan Kragan memiliki luas yaitu $6.166 \mathrm{Ha}$ atau sekitar 6,08\% dari total wilayah Kabupaten Rembang. Berdasarkan jumlah penduduk 10 tahun keatas menurut pekerjaan utama Kecamatan Kragan Tahun 2013, penduduk yang bekerja dibidang perikanan sebesar 7.219 jiwa atau sekitar $15,07 \%$ dari jumlah penduduk, merupakan mata pencaharian terbesar kedua setelah pertanian.

Lokasi yang strategis menghubungkan Kota Semarang menuju Surabaya juga memberikan pengaruh berkembangnya sektor perikanan dan berimplikasi terhadap perkembangan ekonomi wilayahnya. Berdasarkan data dari Dinas Perikanan dan Kelautan Kabupaten Rembang tahun 2013 jumlah produksi dan nilai produksi perikanan laut Kabupaten Rembang selalu meningkat setiap tahunnya. Total produksi pada tahun $20128.666,733$ ton dengan nilai produksi Rp 83.825.356.000,00 menjadi 37.583,359 ton dan nilai produksi Rp 194.644.331.680,00 pada tahun 2013. Untuk menunjang sektor perikanan diperlukan sarana dan prasarana yang memadai. Salah satu sarana penunjang pengembangan perikanan laut di Kecamatan Kragan adalah tersedianya Tempat Pelelangan Ikan (TPI) sebagai tempat pemasaran hasil laut. Adanya 3 TPI di Kecamatan Kragan yaitu TPI Pandangan, TPI Karanglincak dan TPI Karanganyar belum beroperasi secara maksimal. Kondisi fasilitas Tempat Pelelangan Ikan (TPI) yang ada di Kecamatan Kragan saat ini kurang baik, kumuh dan tidak layak seperti yang dikeluhkan oleh para nelayan dan pedagang dilokasi tersebut oleh karena itu memerlukan perhatian dan perbaikan oleh semua pihak yang terlibat. Hal ini yang mendasari pokok permasalahan sehingga dampak yang ditimbulkan adalah kurang maksimalnya hasil produktivitas, pengolahan dan pemasaran ikan di Kecamatan Kragan. Dengan demikian apabila TPI tidak berfungsi dengan semestinya maka transaksi dan penawaran dilakukan diluar lokasi TPI. Selain itu hasil perikanan Kecamatan Kragan juga dipengaruhi oleh keberadaan PPI Tasik Agung di Kecamatan Rembang yang menjadi pusat PPI di Kabupaten Rembang secara keseluruhan. Berdasarkan pada kondisi dan kenyataan tersebut untuk menunjang bagi perkembangan kawasan pesisir di Kabupaten Rembang, khususnya di Kecamatan Kragan, perlu ditentukan lokasi optimal TPI di Kecamatan Kragan, tidak hanya dari sisi lokasi namun juga ketersediaan prasarana dan sarana yang menunjang aktivtas TPI.

\section{DATA DAN METODE}

Wilayah pesisir adalah daerah pertemuan antara darat dan laut; kearah darat wilayah pesisir meliputi bagaian daratan, baik kering maupun terendam air, yang masih dipengaruhi sifat-sifat laut seperti pasang surut, angin laut dan perembesan air asin; sedangkan kearah laut wilayah pesisir mencakup bagian laut yang masih dipengaruhi oleh proses-proses alami yang terjadi di darat seperti sedimentasi dan aliran air tawar, maupun yang disebabkan oleh kegiatan manusia di darat seperti pengundulan hutan dan pencemaran (Dahuri, 1996). Wilayah pesisir dibagi menjadi 4 (empat) kriteria (Budiharsono, 2001), yaitu:

1. Wilayah homogen, sebagai wilayah homogen yang dipandang dari satu aspek/kriteria mempunyai sifat-sifat atau ciri-ciri yang relatif sama. Dengan demikian wilayah pesisir termasuk wilayah homogen dimana pada wilayah pesisir adanya produksi ikan, dan dilihat dari tingkat pendapatan penduduknya tergolong di bawah garis kemiskinan.

2. Wilayah nodal adalah wilayah yang secara fungsional mempunyai ketergantungan antara pusat (inti) dan daerah belakangnya (hinterland). Wilayah pesisir seringkali sebagai wilayah belakang, sedangkan daerah perkotaan sebagai intinya. Sebagai wilayah belakang, wilayah pesisir merupakan penyedia (input) bagi inti, dan merupakan pasar bagi barang-barang jadi (output) dari inti.

3. Wilayah administratif, sebagai wilayah adminstratif wilayah pesisir dapat berupa wilayah administrasi yang relatif kecil yaitu kecamatan atau desa, namun juga dapat berupa kabupaten/kota yang berupa pulau kecil.

4. Wilayah perencanaan, batas wilayah pesisir sebagai wilayah perencanaan lebih ditentukan dengan kriteria ekologis, batas tersebut sering melewati batas-batas satuan wilayah adminstratif, karena pada dasarnya termasuk dalam satu kesatuan wilayah perencanaan yang saling memberikan dampak. 
Sesuai dengan karakteristik yang dimiliki oleh wilayah pesisir tersebut, maka tentunya banyak potensi yang bisa dikembangkan, terutama dari aktivitas masyarakat yang mengandalkan dari hasil perikanan. Menurut Direktorat Jenderal Perikanan Departemen Pertanian RI (1981) dalam Sulistyani (2005), Pelabuhan Perikanan adalah pelabuhan yang secara khusus menampung kegiatan masyarakat perikanan baik dilihat dari aspek produksi, pengolahan maupun aspek pemasarannya. Pelabuhan Perikanan berfungsi sebagai tempat pelayanan umum bagi masyarakat nelayan dan usaha perikanan, sebagai pusat pembinaan dan peningkatan kegiatan ekonomi perikanan yang dilengkapi dengan fasilitas di darat dan di perairan sekitarnya untuk digunakan sebagai pangkalan operasional tempat berlabuh, mendaratkan hasil, penanganan, pengolahan, distribusi dan pemasaran hasil perikanan. Selain pelabuhan perikanan, fasilitas lain yang secara langsung berpengaruh terhadap perkembangan fungsi perikanan dikawasan pesisir adalah adanya TPI yang digunakan sebagai tempat untuk transaksi hasil produksi perikanan.

Agar fungsi TPI tersebut bisa memberikan dampak yang signifikan bagi perkembangan wilayah pesisir secara keseluruhan, perlu adanya lokasi yang optimal yang didasarkan pada beberapa kriteria. Kriteria yang digunakan untuk pemilihan lokasi pengembangan TPI menggunakan pendekatan yang digunakan oleh Pemerintah Kota Semarang dalam mengoptimalkan peran TPI yang ada. Pendekatan ini dilakukan dengan pertimbangan bahwa karakteristik wilayah pesisir di Kota Semarang dan Kabupaten Rembang hampir sama. Kriteria pertimbangan pemilihan lokasi TPI didasarkan pada aspek fleksibilitas lahan, aksesibilitas, utilitas, operasi dan proses kegiatan, biaya pembangunan, citra arsitektur, kondisi perairan untuk operasi kapal perikanan, nilai ekonomi, dan dampak lingkungan.

Tabel 1. Pertimbangan pemilihan lokasi TPI (Bappeda, 2011)

\begin{tabular}{|c|c|c|}
\hline No. & Pertimbangan & Keterangan \\
\hline 1. & Fleksibilitas Lahan & $\begin{array}{l}\text { Berupa ketersediaan lahan bagi pengalokasian TPI dan } \\
\text { kemungkinan perluasannya }\end{array}$ \\
\hline 2. & Aksesibilitas & $\begin{array}{l}\text { Berupa kemudahan pencapaian baik kelokasi TPI maupun kelokasi } \\
\text { pusat-pusat pemasaran tangkapan ikan. }\end{array}$ \\
\hline 3. & Utilitas & Merupakan ketersediaan jaringan prasarana penunjang aktivitas TPI \\
\hline 4. & Operasi dan Proses Kegiatan & $\begin{array}{l}\text { Berupa kemudahan operasi dan proses kegiatan bongkar muat hasil } \\
\text { tangkapan. }\end{array}$ \\
\hline 5. & Biaya Pembangunan & Yakni anggaran biaya yang dibutuhkan dalam pembangunan TPI \\
\hline 6. & Citra Arsitektur & Berupa bangunan dan lingungan sekitar yang terlihat pada lokasi \\
\hline 7. & $\begin{array}{l}\text { Kondisi perairan untuk operasi } \\
\text { kapal perikanan }\end{array}$ & $\begin{array}{l}\text { Perairan yang tenang dengan memungkinkan kapal bersandar lebih } \\
\text { dekat dengan lokasi bongkar muat. }\end{array}$ \\
\hline 8. & Nilai ekonomi & $\begin{array}{l}\text { Berkaitan dengan pengembalian modal dan keuntungan dari investasi } \\
\text { saran TPI serta harga lahan. Untuk kedepannya adalah pemasukan dari } \\
\text { pembangunan TPI. }\end{array}$ \\
\hline 9. & Dampak lingkungan & $\begin{array}{l}\text { Akibat yang ditimbulkan terhadap lingkungan sekitar dengan adanya } \\
\text { pembangunan TPI seperti pencemaran, pendangkalan pantai, dll. }\end{array}$ \\
\hline
\end{tabular}

Keberadaan prasarana dan sarana pada lokasi TPI sangat diperlukan untuk menunjang aktivitas yang dilakukan pada TPI tersebut. Berikut ini profil TPI pandangan, TPI Karanglincak, dan TPI karanganyar.

Tabel 2. Profil TPI Pandangan, TPI Karanglincak, dan TPI Karanganyar ( Dinas Kelautan dan Perikanan Rembang, 2013)

\begin{tabular}{|c|c|c|c|}
\hline Keterangan & TPI Pandangan & TPI Karanglincak & TPI Karanganyar \\
\hline Luas lahan & $0,880 \mathrm{Ha}$ & $192 \mathrm{~m} 2$ & $940 \mathrm{~m} 2$ \\
\hline Luas Bangunan & $452 \mathrm{~m} 2$ & 96 m2 & $650 \mathrm{~m} 2$ \\
\hline Fasiitas & $\begin{array}{l}\text { - } 1 \text { ruang kantor } \\
\text { pengelola } \\
\text { - } 1 \text { los tempat } \\
\text { pelelangan ikan } \\
\text { - Tidak memiliki } \\
\text { Sentra pengolahan } \\
\text { ikan }\end{array}$ & $\begin{array}{l}\text { - } 1 \text { ruang kantor } \\
\text { pengelola } \\
\text { - } 1 \text { los tempat } \\
\text { pelelangan ikan } \\
\text { - Tidak memiliki } \\
\text { Sentra pengolahan } \\
\text { ikan }\end{array}$ & $\begin{array}{l}\text { - } 1 \text { ruang kantor pengelola } \\
\text { - } 31 \text { los tempat pelelangan ikan } \\
\text { - memiliki Sentra pengolahan } \\
\text { ikan, stasiun pengisian bahan } \\
\text { bakar nelayan, tempat labuh } \\
\text { kapal }\end{array}$ \\
\hline
\end{tabular}




\begin{tabular}{|c|c|c|c|}
\hline Kapal motor & $>30 \mathrm{GT}=130$ unit & 5-10 GT = 250 unit & 10-30 GT = 350 unit \\
\hline Alat tangkap & Purseseine $=103$ unit & $\begin{array}{l}\text { Gillnet }=200 \text { unit } \\
\text { Trammelnet }=70 \text { unit } \\
\text { Cantrang = } 70 \text { unit } \\
\text { Dogol = } 200 \text { unit }\end{array}$ & Purseseine $=350$ unit \\
\hline $\begin{array}{l}\text { Sarana pemasaran } \\
\text { bergerak (SPG) }\end{array}$ & $\begin{array}{l}\text { Kendaraan roda } 2=1 \\
\text { unit }\end{array}$ & $\begin{array}{l}\text { Kendaraan roda } 4=1 \\
\text { unit } \\
\text { Kendaraan roda } 3=10 \\
\text { unit } \\
\text { Kendaraan roda } 2=10 \\
\text { unit } \\
\text { Keranjang = } 250 \text { unit }\end{array}$ & - \\
\hline Akses jalan & Jalan desa & Jalan desa & Jalan desa \\
\hline Jaringan listrik & 450 watt & 450 watt & 450 watt \\
\hline Sumber air & Sumur & sumur & sumur \\
\hline Sarana kebersihan & 1 pompa air & - & $\begin{array}{l}\text { Pompa air, dan mempunyai } \\
\text { saluran pembuangan air }\end{array}$ \\
\hline
\end{tabular}

Selain prasarana dan sarana, masing-masing TPI mempunyai sumber daya manusia yang berbeda. Berikut ini ketersediaan sumber daya manusia yang dimiliki oleh TPI yang terdapat di kecamatan Kragan.

Tabel 3. Sumber Daya Manusia di TPI Pandangan, TPI Karanglincak, dan TPI Karanganyar (Dinas Kelautan dan Perikanan Rembang, 2013)

\begin{tabular}{lllll}
\hline No & Jenis & TPI Pandangan & TPI Karanglincak & TPI Karanganyar \\
\hline 1. & Jumlah pengolah & - & 30 & 6 \\
2. & Jumlah pemasar ikan segar & 16 orang & 15 & 20 \\
3. & Jumlah pemasar ikan olahan & - & 15 & 15 \\
4. & $\begin{array}{l}\text { Jumlah pemasar ikan segar maupun } \\
\text { olahan }\end{array}$ & - & 30 & 15 \\
5. Jumlah karyawan TPI & 11 & 7 & 22 \\
6. & Jumlah nelayan & 2510 & 1000 & 5500 \\
\hline
\end{tabular}

Metode yang digunakan dalam studi ini adalah metode kuantitatif dengan menggunakan teknik skoring. Selain itu analisis juga dilakukan secara kualitatif, berdasarkan kriteria yang sudah ditentukan sebelumnya. Adapun data yang digunakan berdasarkan data yang diperoleh dari instansi, yaitu Dinas Perikanan dan Kelautan Kabupaten Rembang, serta data yang diperoleh dari hasil wawancara dan observasi lapangan pada ketiga TPI yang menjadi wilayah studi.

\section{HASIL DAN PEMBAHASAN}

\subsection{Analisis Lokasi}

Analisis lokasi dari setiap TPI didasarkan pada beberapa pendekatan, yaitu:

1. Pendekatan Biaya Terkecil

- Jarak TPI Pandangan ke sumber bahan mentah \pm 20 m karena berada dipinggir pantai utara jawa, dan dekat dengan daerah pemasaran yaitu Pasar Sumbergayam dengan jarak $\pm 1 \mathrm{Km}$.

- Jarak TPI Karanglincak ke sumber bahan mentah \pm 20 m, dan jarak ke daerah pemasar yaitu Pasar Karangharjo $\pm 0,5 \mathrm{Km}$.

- jarak TPI Karanganyar ke sumber bahan mentah \pm 35 m, dekat dengan daerah pemasaran yaitu pasar Kebloran dengan jarak $\pm 1 \mathrm{Km}$. 


\section{Pendekatan Daerah Pemasaran}

Distribusi dari hasil perikanan dan kelautan dapat dilakukan di dalam dan keluar daerah, jika pemasaran keluar daerah dapat dilihat seberapa jauh pemasaran tersebut dan membentuk pasarpasar baru untuk memudahkan pendistribusian hasil tangkapan. Secara keseluruhan pendistribusian hasil perikanan sekitar 30\% didistribusikan di Kecamatan Kragan sendiri, selain pemasaran di TPI juga dilakukan pemasaran di pasar-pasar lokal baik berupa ikan segar maupun ikan hasil olahan. 70\% didistribusikan keluar daerah seperti Semarang, Demak, Blora dan Surabaya. TPI Karanganyar dan Karanglincak lebih banyak didistribusikan ke arah Blora dan Jawa Timur, sedangkan dari TPI Pandangan Wetan banyak didistribusikan ke Demak.

\section{Pendekatan Keuntungan Maksimum}

Lokasi optimal merupakan keuntungan terbesar yang dapat diperoleh, baik dari biaya yang dikeluarkan maupun penerimaan berdasarkan lokasinya. Dalam hal ini lokasi optimal dilihat berdasarkan jumlah produksi dan distribusi ikan paling tinggi di TPI tersebut untuk mendapatkan keuntungan yang maksimum.

- TPI Pandangan memiliki jumlah produksi menengah, tetapi didukung dengan berbagai faktor seperti kelengkapan fasilitas dan daya dukung kawasan. TPI ini dapat beroperasi lebih optimal untuk meningkatkan hasil produksi menjadi tinggi.

- TPI Karanglincak memiliki jumlah produksi paling rendah, hal ini bisa disebabkan karena fasilitas yang kurang. Tetapi jika dikembangkan akan meningkatkan hasil produksi karena di TPI ini memiliki sumber daya manusia yang memadai. Untuk alat tangkap TPI Karanglincak memiliki alat lebih lengkap.

- Dilihat dari jenis ikan, jumlah produksi dan nilai produksi perikanan laut di TPI Karanganyar paling tinggi. Banyak faktor yang mendukung hal tersebut seperti ketersediaan sarana dan prasarana yang lengkap, jumlah sumber daya manusia yang memadai, bentang lahan yang mendukung.

Dari teori lokasi dengan ketiga pendekatan-pendekatannya tersebut, untuk meningkatkan nilai ekonomi Kecamatan Kragan maka dapat diambil kesimpulan bahwa :

1. TPI Pandangan melalui pendekatan biaya terkecil yaitu dekat dengan sumber bahan mentah dan daerah pemasaran. Untuk distribusi pemasaran yaitu dekat dengan Semarang dan Demak. Untuk pendekatan keuntungan maksimum, faktor yang menguatkan untuk dijadikan lokasi optimal adalah ketersediaan fisik yaitu lahan yang luas, sehingga untuk pengembangan kedepannya, jika semua sarana (penambahan jumlah alat tangkap dan kapal motor), prasarana (seperti perbaikan jalan menuju lokasi TPI, menyediakan sarana persampahan, memperbaiki saluran drainase, menyediakan tempat pengolahan limbah) dan mendirikan sentra pengolahan ikan atau industri pengolahan ikan. Dari hal tersebut juga dapat membuka lapangan pekerjaan baru bagi masyarakat maka TPI ini dapat beroperasi lebih optimal untuk meningkatkan hasil produksi lebih tinggi.

2. TPI Karanglincak melalui pendekatan biaya terkecil yaitu dekat dengan sumber bahan mentah dan daerah pemasaran. Untuk distribusi pemasaran yaitu dekat dengan Blora dan Jawa Timur. Untuk pendekatan keuntungan maksimum, TPI Karanglincak memiliki jumlah produksi paling rendah, tetapi bisa dikembangkan karena di TPI ini memiliki sumber daya manusia yang memadai dan alat tangkap ikan yang lebih lengkap.

3. TPI Karanganyar melalui pendekatan biaya terkecil yaitu dekat dengan sumber bahan mentah dan daerah pemasaran. Untuk distribusi pemasaran yaitu ke arah Blora. 


\subsection{Analisis Kelengkapan Prasarana dan Sarana}

Analisis ini didasarkan pada ketersediaan prasarana dan sarana penunjang aktivitas di setiapTPI, yang kemudian digunakan untuk menentukan ranking prioritas sebagai lokasi optimal TPI.

a. Kriteria kelangkapan fasilitas

\begin{tabular}{ccccccc}
\hline Nilai & $\begin{array}{c}\text { Ketersediaan } \\
\text { kantor } \\
\text { pengelola }\end{array}$ & $\begin{array}{c}\text { Los pelelangan } \\
\text { yang memadai }\end{array}$ & $\begin{array}{c}\text { Tempat } \\
\text { parkir }\end{array}$ & $\begin{array}{c}\text { Sentra } \\
\text { pengolahan } \\
\text { ikan }\end{array}$ & $\begin{array}{c}\text { Stasiun } \\
\text { pengisian bahan } \\
\text { bakar nelayan }\end{array}$ & $\begin{array}{c}\text { Tempat } \\
\text { labuh } \\
\text { kapal }\end{array}$ \\
\hline Nilai 3 & $\mathrm{V}$ & $\mathrm{V}$ & $\mathrm{V}$ & $\mathrm{V}$ & $\mathrm{V}$ & $\mathrm{V}$ \\
Nilai 2 & $\mathrm{V}$ & $\mathrm{V}$ & $\mathrm{V}$ & $\mathrm{v}$ & $\mathrm{x}$ & $\mathrm{x}$ \\
Nilai 1 & $\mathrm{V}$ & $\mathrm{V}$ & $\mathrm{x}$ & $\mathrm{x}$ & $\mathrm{x}$ & $\mathrm{x}$ \\
\hline
\end{tabular}

b. Kriteria fleksibilitas lahan

\begin{tabular}{rcc}
\hline Nilai & Ketersediaan lahan & Kemungkinan perluasan \\
\hline Nilai 3 & Luas & $\mathrm{v}$ \\
Nilai 2 & Cukup & $\mathrm{v}$ \\
Nilai 1 & Terbatas & $\mathrm{x}$ \\
\hline
\end{tabular}

c. Kriteria sarana bergerak dan pemasaran

\begin{tabular}{cccc}
\hline Nilai & Kapal motor & Alat tangkap & SPG \\
\hline Nilai 3 & $\mathrm{v}$ & $\mathrm{v}$ & $\mathrm{v}$ \\
Nilai 2 & $\mathrm{v}$ & $\mathrm{v}$ & $\mathrm{x}$ \\
Nilai 1 & $\mathrm{v}$ & $\mathrm{x}$ & $\mathrm{x}$ \\
\hline
\end{tabular}

d. Kriteria prasarana

\begin{tabular}{rcccc}
\hline Nilai & Akses jalan & Jaringan listrik & Sumber air & Sarana kebersihan \\
\hline Nilai 3 & $\mathrm{v}$ & $\mathrm{v}$ & $\mathrm{v}$ & $\mathrm{v}$ \\
Nilai 2 & $\mathrm{v}$ & $\mathrm{v}$ & $\mathrm{v}$ & $\mathrm{x}$ \\
Nilai 1 & $\mathrm{v}$ & $\mathrm{v}$ & $\mathrm{x}$ & $\mathrm{x}$ \\
\hline
\end{tabular}

e. Kriteria SDM

\begin{tabular}{rccc}
\hline Nilai & Karyawan TPI & Pemasar ikan & Pengolah ikan \\
\hline Nilai 3 & $\mathrm{v}$ & $\mathrm{v}$ & $\mathrm{v}$ \\
\hline Nilai 2 & $\mathrm{v}$ & $\mathrm{v}$ & $\mathrm{x}$ \\
Nilai 1 & $\mathrm{v}$ & $\mathrm{x}$ & $\mathrm{x}$ \\
\hline
\end{tabular}

f. Hasil penilaian

\begin{tabular}{lccc}
\multicolumn{1}{c}{ Kriteria } & TPI Pandangan & TPI Karanglincak & TPI Karanganyar \\
\hline Kelengkapan fasilitas & 2 & 1 & 3 \\
Fleksibilitas lahan & 3 & 1 & 2 \\
$\begin{array}{l}\text { Sarana bergerak dan } \\
\text { pemasaran }\end{array}$ & 3 & 3 & 1 \\
prasarana & 3 & 2 & 3 \\
SDM & 2 & 3 & 3 \\
Ranking & II & III & I \\
\hline
\end{tabular}


Gambar 1. Peta Analisis Ketersediaan Prasarana dan Sarana TPI (Analisis, 2014)

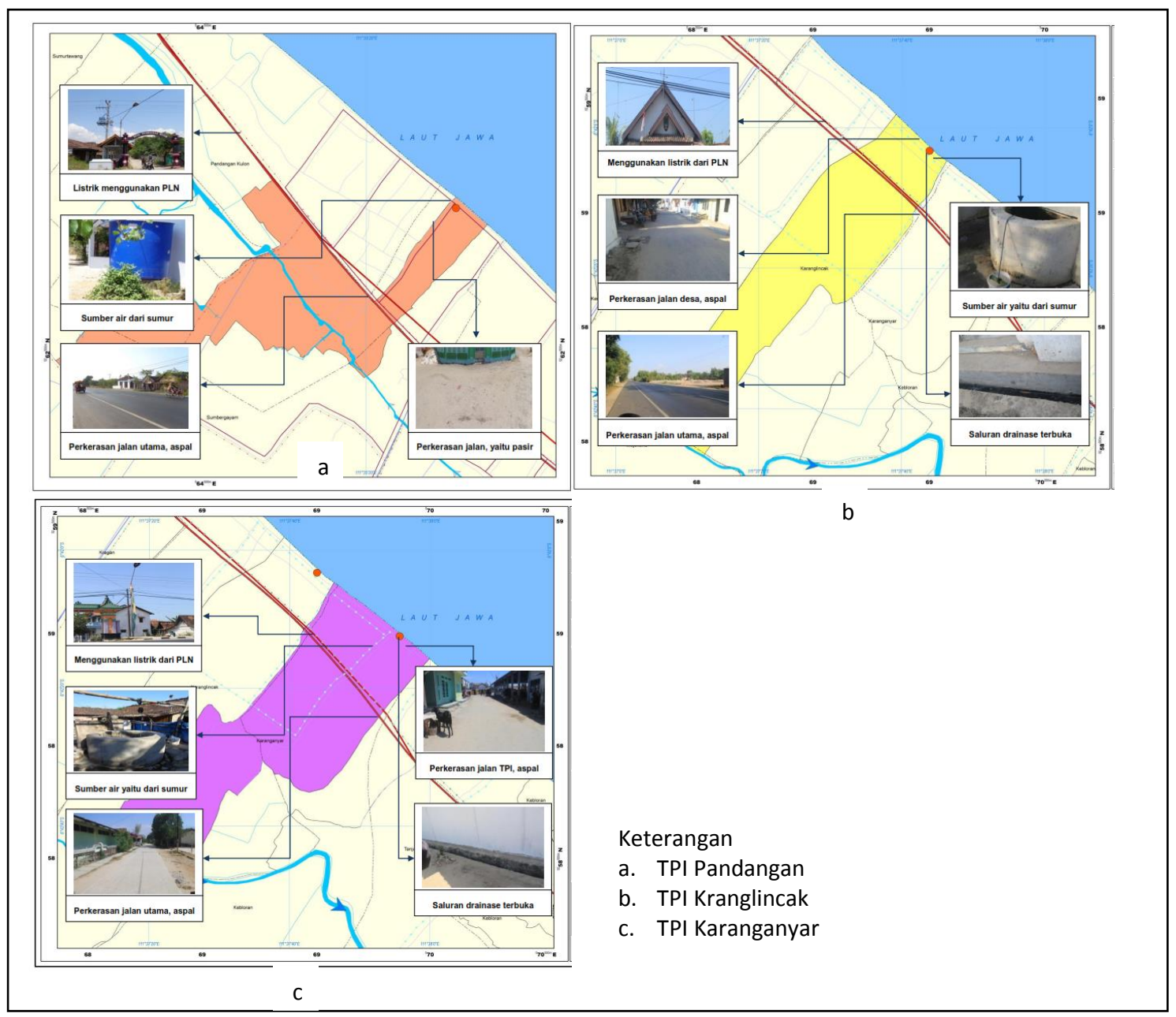

Sesuai dengan analisis penilaian terhadap prasarana dan sarana yang terdapat di masing-masing TPI, diperoleh hasil bahwa lokasi optimal pengembangan TPI yang paling mendukung bagi perkembangan sektor perikanan di kawasan pesisir Kragan adalah di TPI Pandangan.

\section{KESIMPULAN}

Berdasarkan hasil analisis yang dilakukan dengan menggunakan pendekatan lokasi serta ketersediaan prasarana dan sarana yang ada, TPI Pandangan merupakan lokasi optimal bagi pengembangan TPI yang mendukung perkembangan sektor perikanan di Kecamatan Kragan. TPI ini memiliki kemungkinan yang tinggi untuk dikembangkan, karena faktor yang menguatkan untuk dijadikan lokasi optimal adalah ketersediaan fisik yaitu lahan yang luas, sehingga untuk pengembangan kedepannya, jika semua sarana (penambahan jumlah alat tangkap dan kapal motor), prasarana (seperti perbaikan jalan menuju lokasi TPI, menyediakan sarana persampahan, memperbaiki saluran drainase, menyediakan tempat pengolahan limbah) dan mendirikan sentra pengolahan ikan atau industri pengolahan ikan.

Selain itu pada berdasarkan RDTR Kecamatan Kragan, TPI Pandangan termasuk diprioritaskan penanganannya untuk dijadikan kawasan terpadu bahari sebagai sentra perikanan laut dan industri perikanan (agromina). Berdasarkan upaya pengembangan tersebut, diharapkan tujuan dari adanya TPI sesuai dengan yang tercantum dalam Peraturan Daerah Kabupaten Rembang Nomor 4 Tahun 2009 tentang Pengelolaan Tempat Pelelangan Ikan (TPI), yang meliputi memperlancar pelaksanaan penyelenggaraan pelelangan, menjaga dan mengusahakan stabilitas harga ikan, meningkatkan taraf hidup dan kesejahteraan nelayan, melaksanakan pendataan pengelolaan sumber daya ikan, dan meningkatkan pendapatan daerah dapat tercapai 


\section{DAFTAR PUSTAKA}

Aktualisasi Peta Dasar Kabupaten Rembang tahun 2011. Bappeda Kabupaten Rembang.

Budiharsono, Sugeng. 2001. Teknik Analisis Pembangunan Wilayah Pesisir dan Lautan. Jakarta : PT Pradnya Paramita.

Dahuri, R, dkk. 1996. Pengelolaan Sumber Daya Wilayah Pesisir dan Lautan Secara Terpadu. Jakarta : PT Pradnya Paramita.

Dinas Kelautan dan Perikanan Kabupaten Rembang. Laporan Tahunan 2013.

Dyah, Sulistyani. 2005. "Analisis Efisiensi TPI (Tempat Pelelangan Ikan) Kelas 1, 2 dan 3 di Jawa Tengah dan Pengembangannya untuk Peningkatan Kesejahteraan Nelayan". Tesis tidak diterbitkan, Program Studi Magister Manajemen Sumberdaya Pantai, Universitas Diponegoro, Semarang.

Djojodipuro,Marsudi.1992. Teori Lokasi. Jakarta: Lembaga Penerbit Fakultas Ekonomi Universitas Indonesia. Kragan dalam Angka 2013. BPS Jawa Tengah.

Laporan Tahunan 2013. Dinas Kelautan dan Perikanan Kabupaten Rembang.

Peraturan Daerah Kabupaten Rembang Nomor 4 Tahun 2009 tentang Pengelolaan Tempat Pelelangan Ikan Undang-Undang Republik Indonesia Nomor 26 tahun 2007 tentang Penataan Ruang.

Undang-Undang Republik Indonesia Nomor 27 tahun 2007 tentang Pengelolaan Wilayah Pesisir dan PulauPulau Kecil.

Rencana Tata Ruang Wilayah (RTRW) Kabupaten Rembang tahun 2011-2031. 